\title{
Influence of rehydration on transcriptome during resuscitation of desiccated Pseudomonas putida KT2440
}

\author{
Lilia I. López-Lara', Laura A. Pazos-Rojas', Lesther E. López-Cruz' ${ }^{1}$ Yolanda E. Morales-García 1,2, \\ Verónica Quintero-Hernández ${ }^{1,3}$, Jesús de la Torre ${ }^{4}$, Pieter van Dillewijn ${ }^{4}$, Jesús Muñoz-Rojas ${ }^{1,5^{*}}$ and \\ Antonino Baez ${ }^{1,5^{*}}$ (D)
}

\begin{abstract}
Purpose: Pseudomonas putida KT2440 is a desiccation-sensitive bacterium that loses culturability after 15 days of air desiccation. We have previously shown that $P$. putida KT2440 can develop a viable but nonculturable (VBNC) state after being exposed to desiccation stress and eventually recover when desiccated cells are rehydrated for at least $24 \mathrm{~h}$.

Methods: To determine which genes of transport, oxidation-reduction, and transcription processes could be involved in the return of $P$. putida KT2440 to the culturable state, a transcriptome analysis was carried out comparing the gene expression of non-desiccated samples with samples subjected to desiccation followed by 20 min of rehydration or desiccation followed by $24 \mathrm{~h}$ of rehydration.
\end{abstract}

Results: Desiccation stress triggered a VBNC state of $P$. putida. The major response was detected after $24 \mathrm{~h}$ of rehydration with 148 upregulated and 42 downregulated genes. During the VBNC state, P. putida activated transmembrane transport processes like that of siderophores through a TonB-dependent transporter and putative polyhydric alcohol transport systems. Prolonged rehydration with distilled water resuscitated P. putida KT2440 cells activating the catabolism of phenylalanine/tyrosine to provide energy and carbon for ubiquinone biosynthesis while maintaining a reduced protein synthesis. On the other hand, the interruption of the TonB-dependent receptor gene (PP_1446) increased desiccation survival of the mutant strain.

Conclusion: The activation of the iron transport system (TonB-dependent siderophore receptor) and alcohol transport can be helping the VBNC state of $P$. putida. Activation of catabolism of phenylalanine/tyrosine and reduced protein synthesis was needed for resuscitation from the VBNC state.

Keywords: TonB-dependent receptor, Resuscitation, Survival, VBNC

\section{Background}

Beneficial interactions between plants and bacteria greatly favor plant growth and its protection against diseases and pests (Kloepper et al. 1989; Hayat et al. 2010). A successful interaction not only relies on the capabilities of the beneficial bacteria but also on abiotic factors such as temperature, $\mathrm{pH}$, salinity, and water availability that can

\footnotetext{
* Correspondence: joymerre@hotmail.com; antonino.baez@correo.buap.mx ${ }^{1}$ Centro de Investigaciones en Ciencias Microbiológicas, Instituto de Ciencias, Benemérita Universidad Autónoma de Puebla, Puebla, México
} Full list of author information is available at the end of the article disrupt the bacterial-plant interaction (Molina-Romero et al. 2017; Enebe and Babalola 2018). Water limiting conditions affect the viability of the cells and cause loss of membrane integrity, protein denaturation, accumulation of reactive oxygen species (ROS), and DNA damage leading to bacterial death (Potts 1994; Potts et al. 2005; Lebre et al. 2017). Pseudomonas putida KT2440 is a metabolically versatile Gram-negative, gamma-proteobacterium. $P$. putida KT2440 is a plant growth-promoting rhizobacterium (PGPR) able to colonize the rhizosphere of several plants, degrade organic pollutants, and fight plant diseases

(c) The Author(s). 2020 Open Access This article is licensed under a Creative Commons Attribution 4.0 International License, which permits use, sharing, adaptation, distribution and reproduction in any medium or format, as long as you give appropriate credit to the original author(s) and the source, provide a link to the Creative Commons licence, and indicate if changes were made. The images or other third party material in this article are included in the article's Creative Commons licence, unless indicated otherwise in a credit line to the material. If material is not included in the article's Creative Commons licence and your intended use is not permitted by statutory regulation or exceeds the permitted use, you will need to obtain permission directly from the copyright holder. To view a copy of this licence, visit http://creativecommons.org/licenses/by/4.0/. 
(Molina et al. 2000; Espinosa-Urgel et al. 2002; Nelson et al. 2002; Belda et al. 2016).

Despite the metabolic adaptability of $P$. putida KT2440, its survival decreases drastically under reduced water availability (Manzanera et al. 2002; Pazos-Rojas et al. 2019). P. putida KT2440 loses culturability after 15 days of desiccation in a controlled chamber $\left(50 \%\right.$ relative humidity and $\left.30^{\circ} \mathrm{C}\right)$ entering into the viable but nonculturable (VBNC) state but can return to the cultivable state after interaction with maize root exudates or $24 \mathrm{~h}$ of rehydration (Molina-Romero et al. 2017; Pazos-Rojas et al. 2019). The VBNC state can be considered a long-term survival strategy of bacterial cells or as a deteriorated state of the cells that lead to death (Ducret et al. 2014). Desiccated $P$. putida cells have impaired culturability and membrane integrity but maintain active gene expression as shown by the expression and synthesis of an introduced GFP reporter protein (Pazos-Rojas et al. 2019).

VBNC bacteria might recover culturability under suitable conditions. For example, Legionella pneumophila is resuscitated by contact with amoebae or by amending agar plates with compounds that reduce the formation of reactive oxygen species (ROS) (Ducret et al. 2014). The culturability of Lactobacillus harbinensis is recovered by the addition of catalase rather than by a temperature upshift (Liu et al. 2018). Escherichia coli and $P$. aeruginosa resuscitate by incubation in LB broth at $37^{\circ} \mathrm{C}$ after UV (Zhang et al. 2015) or chlorine treatment (Chen et al. 2018). Acidovorax citrulli and $P$. aeruginosa regain culturability immediately after copper ion chelation (Bédard et al. 2014; Kan et al. 2019).

Regarding the mechanisms to cope with desiccation stress, some bacteria maintain the integrity of the membrane during drought stress by increasing de novo synthesis of trehalose that acts as an osmoprotectant (Purvis et al. 2005; Zhang and Yan 2012). P. putida and other soil bacteria induce the synthesis of exopolysaccharides and biofilm formation during water limitation to retain water and to ensure a moist microenvironment to handle drying conditions (Roberson and Firestone 1992; Chang et al. 2007). The mechanism through which $P$. putida KT2440 enter the VBNC state upon desiccation stress and resuscitate after rehydration remains poorly investigated. Here, we studied the transcriptome of $P$. putida KT2440 subjected to desiccation stress followed by rehydrating to identify genes potentially involved in the resuscitation of VBNC $P$. putida cells. Results suggest that activation of the iron transport system through a TonB-dependent receptor could be helping the VBNC state of P. putida KT2440.

\section{Results}

Culturable cell counts of $P$. putida KT2440 under air desiccation $\left(30^{\circ} \mathrm{C}\right.$ and $50 \%$ relative humidity) and transcriptional analysis

Bacterial samples that were subjected to air desiccation dry completely becoming powder after 6 days. After 15 days of air desiccation, the culturable cell counts of $P$. putida KT2440 decreased from $10^{10} \mathrm{CFU} / \mathrm{mL}$ to $0 \mathrm{CFU} /$ $\mathrm{mL}$ (Fig. 1). However, when desiccated bacterial samples were rehydrated for at least $24 \mathrm{~h}$, the culturable cell counts were as high as $10^{4} \mathrm{CFU} / \mathrm{mL}$. We previously described that $P$. putida KT2440 can enter the viable but nonculturable (VBNC) state during desiccation stress and return to the culturable state after $24 \mathrm{~h}$ of rehydration (Pazos-Rojas et al. 2019). To determine which genes could be involved in the return of $P$. putida KT2440 to the culturable state, a transcriptome analysis was carried out comparing the gene expression of non-desiccated samples with samples subjected to desiccation followed by either 20-min rehydration (VBNC state) or 24-h rehydration (resuscitation from the VBNC state). The major response of air-desiccated cells was detected after $24 \mathrm{~h}$ of rehydration with 148 upregulated genes and 42 downregulated genes (Fig. 2). The response after 20 min of rehydration was lower in terms of differentially expressed genes, with only 6 upregulated genes. These genes were related to transmembrane transport and oxidation-reduction processes (Table 1). The complete list of differentially expressed genes after $24 \mathrm{~h}$ of rehydration and their fold changes are presented in Table S1 in the supplemental material. A total of $56 \%$ of differentially expressed genes after $24 \mathrm{~h}$ of rehydration are associated with biological process GO terms. The function of the upregulated genes is mainly involved in transport, oxidationreduction processes, and regulation of transcription (Fig. 3). The functional annotation and overrepresentation of GO terms $(P<0.05)$ of the upregulated functional group of genes belonging to the transport process included the peptide $\mathrm{ABC}$ transporter substrate-binding protein (PP_4146), microcin C ABC transporter substrate-binding protein (PP_4147), membrane protein (PP_3561), EmrB/QacA family drug

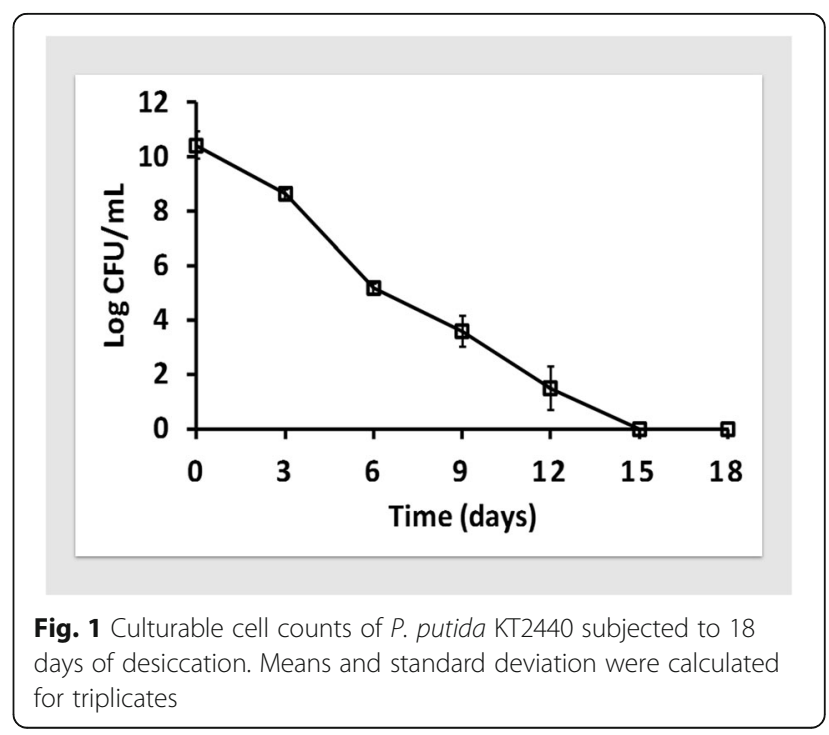




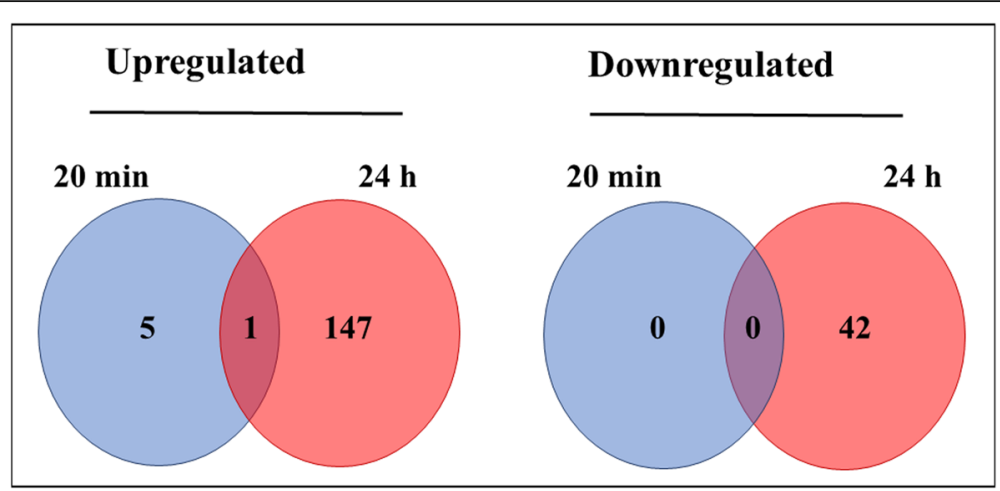

Fig. 2 Venn diagrams showing statistically significant $(p<0.05)$ up- and downregulated genes in the desiccated-rehydrated cells relative to nondesiccated control cells from P. putida KT2440 in microarray analyses. Values shown represent more than 2-fold differential expression. Twenty minutes and $24 \mathrm{~h}$ indicate the bacterial cells which were desiccated for 18 days and then rehydrated for 20 min or 24 h, respectively, before RNA extraction. Microarray analyses were performed in triplicate for each condition

resistance transporter (PP_2067), MFS transporter (PP_ 2651), 4-hydroxybenzoate transporter (PP_1376), ribose ABC transporter ATP-binding subunit (PP_2455), C4dicarboxylate transport protein (PP_1188), pyoverdine ABC transporter ATP-binding protein/permease (PP_4216), and nickel ABC transporter ATP-binding protein (PP_3346) (Table S1). The functional annotation clustering also revealed the enrichment of gene products involved in regulation of transcription such as RNA polymerase sigma-70 factor (PP_3086), AraC family transcriptional regulator ( $\mathrm{PP}_{-}$ 2072), LuxR family transcriptional regulator (PP_0574), transcriptional regulator (PP_0175), 2-ketogluconate utilization repressor(ptxS) (PP_3380), GntR family transcriptional regulators (PP_2253 and PP_0204), LysR family transcriptional regulator (PP_2250), and TetR family transcriptional regulators (PP_4754, PP_2475, PP_2951). Another overrepresented functional group was the biosynthesis of amino acids, particularly phenylalanine and tyrosine biosynthesis which involved the upregulation of shikimate 5-dehydrogenase ( $\mathrm{PP}_{-}$ 3768), 3-dehydroquinate synthase (aroB) (PP_5078), and fructose-bisphosphate aldolase (fba) (PP_4960) (Supplemental Figure S3). The upregulation of 2-Cys peroxiredoxin (tpx) (PP_3587), thioredoxin (trxC) (PP_5069), and glutaredoxin (grxC) (PP_5054) suggested activation of the antioxidant defense or cell stress response since these enzymes can also perform the function of molecular chaperones. The

Table 1 Upregulated genes of 20 min rehydrated P. putida KT2440 cells obtained by DNA microarray

\begin{tabular}{lll}
\hline Locus name & Annotation & Fold change \\
\hline PP_2676 & Substrate-binding protein & 4.4 \\
PP_2662 & Ethylene glycol porin & 4.88 \\
PP_3451 & Hypothetical protein & 2.31 \\
PP_0880 & dppC-dipeptide ABC transporter permease & 4.30 \\
PP_1446 & TonB-dependent receptor & 5.16 \\
PP_0256 & Molybdopterin oxidoreductase subunit & 4.58 \\
\hline
\end{tabular}

downregulated genes after $24 \mathrm{~h}$ of rehydration included genes related to translation, oxidation-reduction processes, regulation of transcription, transport, and biosynthetic processes (Fig. 3). The downregulation of PP_2467, PP_0454, PP_0446, PP_0459 encoding for 50S ribosomal proteins, and the downregulation of PP_4709 (rpsO gene) encoding 30S ribosomal protein suggested a limited translation capability of these cells. Furthermore, the PP_4000 gene encoding serine-tRNA ligase was also downregulated. There was downregulation of the LysR family transcriptional regulator (PP_2695), integration host factor subunit beta (gene ihfB, PP_1773), and RNA polymerase sigma 70 factor (gene rpoD, PP_0387). Since RNA polymerase sigma factor RpoD is the primary sigma factor during exponential growth, its repression agrees with the non-growing state of desiccated-24-h rehydrated cells caused by the lack of nutrients in the sterile distilled water. The repression of $r p o D$ and genes encoding $50 \mathrm{~S}$ and $30 \mathrm{~S}$ proteins was in line with the fact that sigma 70-RNA polymerase transcribes genes encoding ribosomal proteins. The PP_1914, PP_3839, PP_3433, and PP_4258 genes coding for oxidoreductases were downregulated in desiccated-24-h rehydrated cells (Supplementary Table S1). The downregulation of the PP_1914 gene which codes for the 3-oxoacyl-ACP reductase subunit probably affected fatty acid biosynthesis while the downregulation of PP_3433 (4hydroxyphenylpyruvate dioxygenase) might be impairing the phenylalanine/tyrosine catabolism at the phenylpyruvate node diverting carbon flow to phenylacetaldehyde and phenyllactate nodes (Supplemental Figure S4).

\section{Desiccation tolerance of $P$. putida KT2440 and its mutants} Considering that the six upregulated genes after $20 \mathrm{~min}$ of rehydration could be involved in triggering the cascade leading to the resuscitation from the viable but nonculturable state, four for which $P$. putida KT2440 mutant strains $\left(\Delta \mathrm{PP} \_3451, \Delta \mathrm{PP} \_0880, \Delta \mathrm{PP} \_1446, \Delta \mathrm{PP} \_0256\right)$ were available in the Pseudomonas Reference Culture Collection 


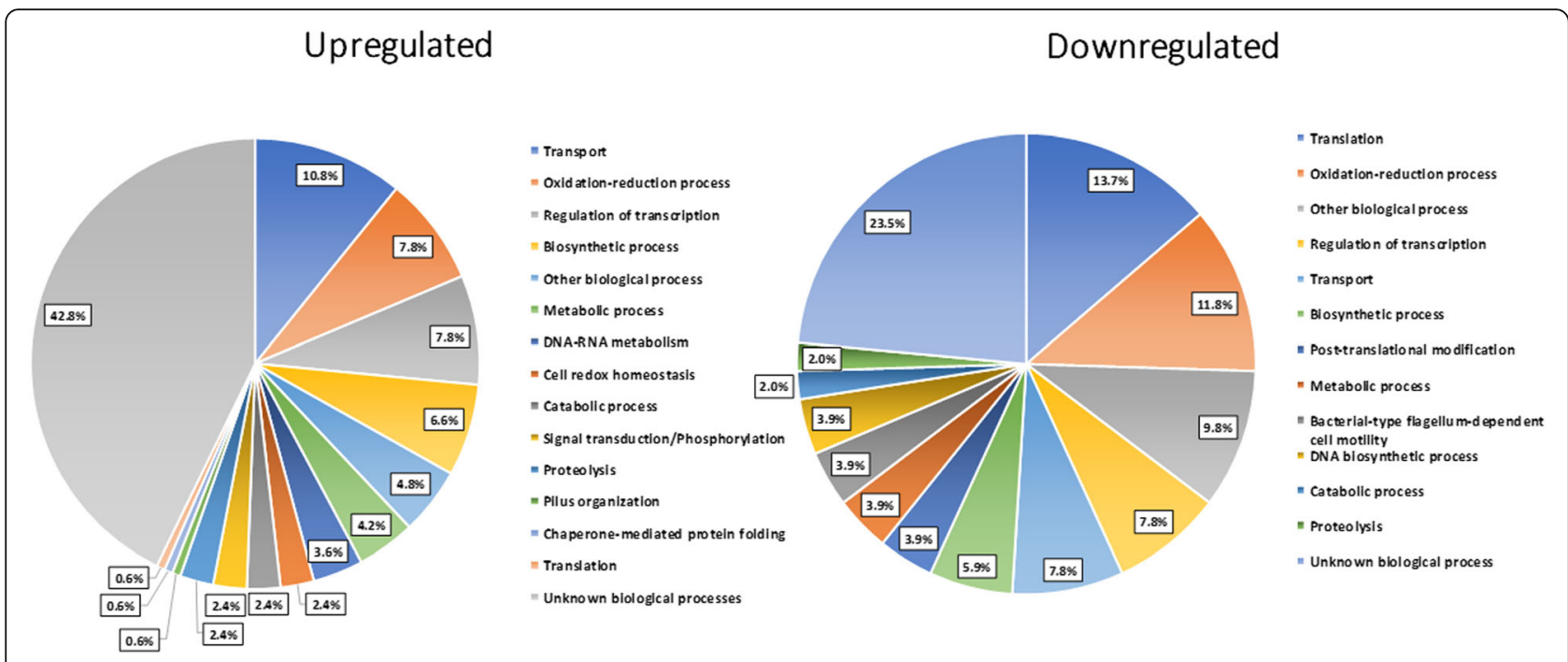

Fig. 3 Functional categories of statistically significant $(p<0.05)$ differentially expressed genes in desiccated P. putida KT2440 cells followed by 24 h rehydration

of the EEZ-CSIC (http://artemisa.eez.csic.es/prcc/) were studied in greater detail to evaluate their involvement in desiccation-rehydration tolerance (Fig. 4). The $\triangle$ PP_0880 and $\triangle \mathrm{PP} \_1446$ mutants are interrupted in a dppCdipeptide $\mathrm{ABC}$ transporter permease and a TonBdependent receptor, respectively. The PP_0256 gene encodes a molybdopterin oxidoreductase subunit and the PP 3451 gene encodes a hypothetical protein (Table 1). There was no difference in the desiccation tolerance between the mutant strains and the wild type as almost all dropped to 0 $\mathrm{CFU} / \mathrm{mL}$ after 15 days of desiccation, except for the $\Delta \mathrm{PP}$ 1446 mutant which survived 18 days of desiccation with $10^{3} \mathrm{CFU} / \mathrm{mL}$ (Fig. 4). When 18 days-desiccated samples were rehydrated for $24 \mathrm{~h}$, the $\log _{10}$ culturable cells (CFU/ $\mathrm{mL}$ ) were $3.17 \pm 0.03,2.81 \pm 0.30,3.32 \pm 0.02,3.66 \pm 0.07$, $3.50 \pm 0.19$ for P. putida KT2440, $\Delta$ PP_0256, $\Delta$ PP_3451, $\triangle \mathrm{PP} \_0880$, and $\triangle \mathrm{PP} \_1446$, respectively. This result suggests that none of the mutations were essential for the resuscitation of the viable but non-culturable state.

Exposure of $\Delta \mathrm{PP} \_3451, \Delta \mathrm{PP} \_0880$, and $\Delta \mathrm{PP} \_0256 \mathrm{mu}-$ tants to 18 days of desiccation resulted in similar cell viability relative to the wild-type cells subjected to identical conditions (Fig. 4); therefore, we decided to explore if these selected genes that were found to be upregulated upon 20min rehydration were also overexpressed in desiccated cells prior rehydration. Thus, the qRT-PCR analysis was performed for the parental strain subjected to 18 days of desiccation (Fig. 5). Compared with non-desiccated samples (BD), the transcription levels of PP_1446 and PP_0256 genes increased significantly in the desiccated cells without rehydration (WoR condition). This overexpression of $\mathrm{PP}_{-}$ 1446 (TonB-dependent receptor) and PP_0256 (molybdopterin oxidoreductase subunit) was maintained regardless of posterior 20-min or 24-h rehydration (Fig. 5). PP_3451 gene expression increased significantly only after $20 \mathrm{~min}$ and 24 $\mathrm{h}$ of rehydration while the expression of PP_0880 did not increase under any of the conditions evaluated. A qRT-PCR analysis of PP_2676 and PP_2662 was also performed (Supplemental Figure S1) and the results show that both are expressed in desiccated cells and after rehydration periods, thereby both displayed a similar expression trend to that observed by microarray (Table 1). In summary, five of the six genes displayed a similar expression profile obtained by both microarray and qRT-PCR at 20-min rehydration.

\section{Discussion}

In other research works where $P$. putida is subjected to mild water limitation, bacteria upregulate gene expression of processes related to transcription, biosynthesis,

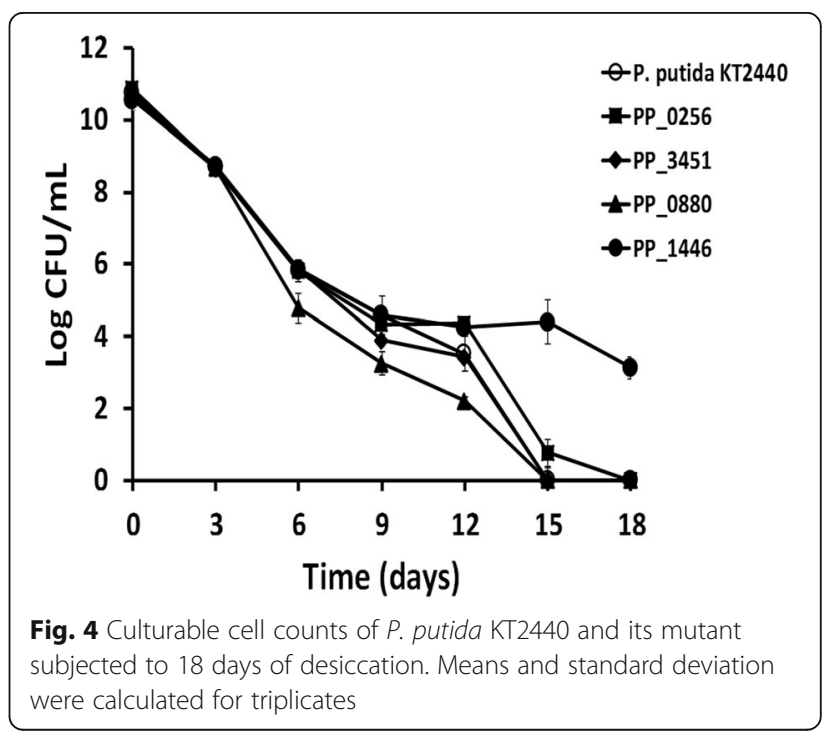




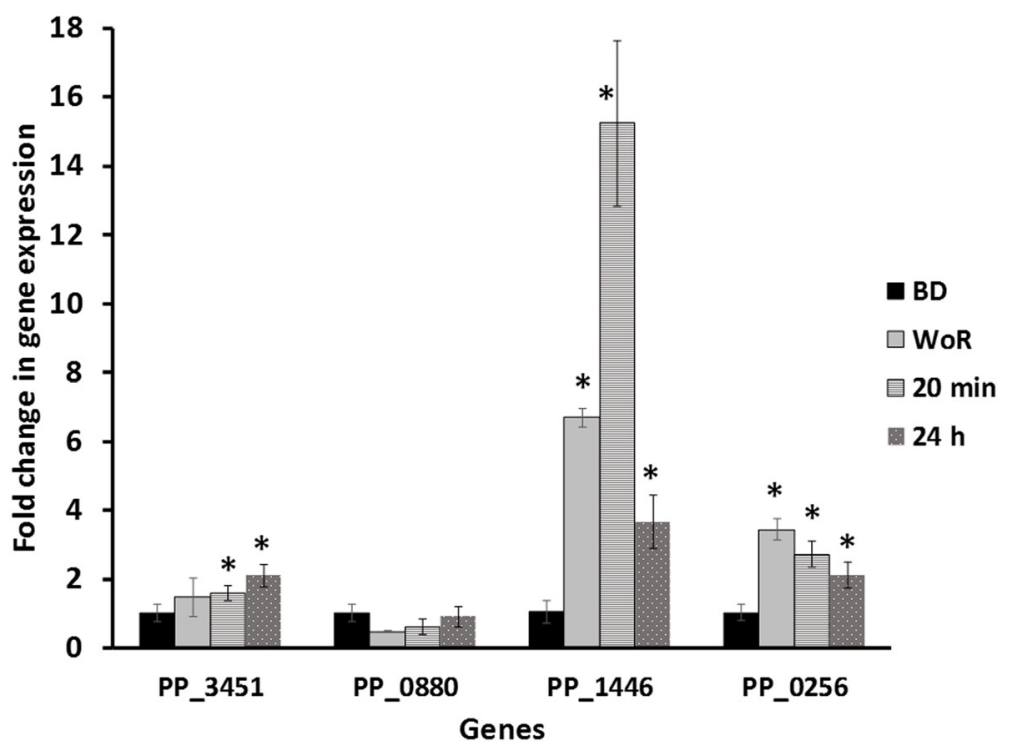

Fig. 5 qRT-PCR analysis of genes PP_3451, PP_0880, PP_1446, and PP_0256 in desiccated P. putida KT2440 wild-type cells followed by rehydration. "BD" means before desiccation and refers to non-desiccated cells. WoR indicates that RNA was extracted from desiccated bacteria prior to rehydration. Twenty minutes and $24 \mathrm{~h}$ indicate that 18 days-desiccated bacteria were rehydrated for $20 \mathrm{~min}$ or $24 \mathrm{~h}$ before RNA extraction. Error bars represent the standard deviation of three replicates. ${ }^{*}$ Indicates statistical significance $(p<0.005)$

and degradation of surface polysaccharides, and cell envelope; while differentially regulate the transport and binding proteins (Gülez et al. 2012; Gulez et al. 2014). In this work, desiccated P. putida KT2440 cells upon $24 \mathrm{~h}$ of rehydration upregulated biological processes related to transport, oxidation-reduction, regulation of transcription, and biosynthetic process while downregulated biological processes related with translation, oxidationreduction, and the regulation of transcription. This upand downregulation of genes within similar role categories is common in the water stress response of $P$. putida KT2440 (Gülez et al. 2012). Genes encoding for products classified within the same biological process can act on different pathways. Thus, PP_3768 and PP_3839 belonging to the same biological process GO term, oxidation-reduction process, were up- and downregulated, respectively (Fig. 3, Supplemental Table S1) probably playing roles within specific pathways. The PP_3768 gene encoding shikimate 5-dehydrogenase was upregulated because it is required for phenylalanine/tyrosine biosynthesis while the PP_3839 gene encoding alcohol dehydrogenase was downregulated to decrease, probably, the reduction and oxidation of aldehydes and alcohols.

During water stress, Pseudomonas cells produce alginate to create a hydrated microenvironment while accumulating intracellular organic osmolytes like trehalose, betaine, ectoine, $\mathrm{N}$-acetylglutaminylglutamine amide, Ala, Gly, Glu, Ser, Thr, Asp, glucosylglycerol, and mannitol (Pocard et al. 1994; Kets et al. 1996; Paul and Nair 2008; Kurz et al. 2010). After 18 days of desiccation, desiccated P. putida cells lost their cultivability and probably accumulated a high number of compatible solutes. Twenty-four hours of rehydration with sterile distilled water resuscitated dormant cells with bacterial counts of $10^{3}-10^{4} \mathrm{CFU} / \mathrm{mL}$ but it could also cause a hypoosmotic shock driving water into the cells. To cope with the resulting increase of turgor pressure, bacteria probably release the stockpile osmolytes to reduce the driving force for water entry. The sudden addition of water to the environment, such as during a rainstorm, is a typical hypoosmotic stress faced by soil bacteria and it was exactly what we were looking for with this experiment. It is important to mention that distilled water does not lyse P. putida cells as observed by transmission electron microscopy analysis (Pazos-Rojas et al. 2019). Thus, after $24 \mathrm{~h}$ of starvation and osmotic down-shock, $P$. putida activated the RrbsA-I ribose ABC transporter (PP_2455), GlnL/GlnG twocomponent system sensor histidine kinase/phosphatase (PP_5047) which senses $\mathrm{N}_{2}$ availability, and the SpuB Glutamylpolyamine synthetase (PP_5183), and DctA C4 dicarboxylate (succinate, malate, L-aspartate, oxaloacetate) transport protein (PP_1188) for carbon and nitrogen uptake. Although distilled water contains no nutrients, trace amounts of ribose, amino acids, and organic compounds released by dead cells or during the hypoosmotic shock could be available in this medium. Starvation induces the stringent response producing the alarmones guanosine tetraphosphate (ppGpp) and guanosine pentaphosphate (pppGpp) through the enzymes RelA and SpoT homologs (Liu et al. 2017). Although the transcription levels of relA and spoT were not affected after $24 \mathrm{~h}$ of rehydration, the inhibition of ribosome protein biosynthesis and repression of RpoD, two targets of (p)ppGpp, suggest an active stringent response in 
these rehydrated cells (Zhang et al. 2019). Besides, the activation of pyoverdine transporter, a siderophore upregulated by (p)ppGpp, agrees with the stringent control (Vogt et al. 2011; Zhang et al. 2019). Other potential starvation-survival strategy used by desiccated-24-h rehydrated cells was the activation of phenylalanine/tyrosine biosynthesis (Supplemental Figure S3) and phenylalanine degradation (Supplemental Figure S4). This result suggests that desiccatedrehydrated $P$. putida cells obtain nitrogen from the catabolism of this amino acid (Herrera et al. 2012). Furthermore, the repression of pde encoding 3',5'-cyclic-AMP phosphodiesterase (PP_4917) can be increasing the cAMP pool mediating the utilization of phenylalanine and tyrosine as nitrogen sources by cAMP-CRP (Herrera et al. 2012; Green et al. 2014). The carbon flow coming from phenylalanine can be deflecting, at the phenylpyruvate node, to ubiquinone biosynthesis, which agrees with the activation of UbiA ( $\mathrm{PP}_{-}$ 5318), the regulatory enzyme of the overall ubiquinone pathway (Supplemental Figure S4). Ubiquinone is used as a cofactor of quinone-dependent alcohol dehydrogenases (PP_2674, PP_2679) and electron carriers in the oxidative phosphorylation. The complex I (NADH dehydrogenase) of 24-h rehydrated cells was activated as suggested by the upregulation of the nuoG gene (PP_4124) while the CcoP-II gene of cytochrome c oxidase complex was repressed indicating that the electron transport chain was working partially and that the energy state of the cells was low. Finally, the reduced protein synthesis in desiccated-24-h rehydrated cells, as suggested by the repression of genes encoding $50 \mathrm{~S}$ and $30 \mathrm{~S}$ ribosomal proteins, is a hallmark of "persister" or VBNC cells (Song and Wood 2020).

P. putida KT2440 lost cultivability after 15 days of air desiccation (Fig. 1), entering the VBNC state while maintaining the upregulation of five of six genes detected after $20 \mathrm{~min}$ of rehydration (Table 1). The function of these genes could be of importance to maintain the viable but nonculturable (VBNC) state or to resuscitate from the VBNC state since five of these genes were highly upregulated in desiccated (VBNC cells) and desiccated-shortly rehydrated cells (Fig. 5, supplemental Figure S1). It is interesting that PP_2676, a gene encoding for a substrate-binding protein of an $A B C$ importer, was upregulated in all conditions tested (desiccated, desiccated-20-min rehydrated, and desiccated-24-h rehydrated cells) by both microarray and qRT-PCR analysis. Unfortunately, the $\triangle \mathrm{PP} \_2776$ mutant strain was not available to evaluate its behavior under desiccation stress. The TonB-dependent receptor (PP_1446), substrate-binding protein (PP_2676), ethylene glycol porin (PP_2662), hypothetical protein (PP_3451), and molybdopterin oxidoreductase subunit (PP_0256) genes were found to be upregulated by the qRT-PCR analysis in both desiccated (WoR) and desiccated-20-min rehydrated cells (Fig. 5, Supplemental Figure S1). Molybdopterin oxidoreductases play essential roles in bacteria, some of them are required for persistence during pathogenesis, protection of periplasmic proteins from oxidative damage, and degradation of nicotine (Williams et al. 2015; Gennaris et al. 2015; Xia et al. 2018). The role of molybdopterin oxidoreductase in desiccated $P$. putida cells is unknown but it will be interesting to explore any protecting effect on proteins of the periplasm against oxidation stress. The porin, PP_2662, and the substratebinding protein, PP_2676, are involved in the exchange of ethylene glycol and its oxidation products across the outer membrane during the degradation of ethylene glycol and other alcohols via quinoprotein alcohol dehydrogenases (Mückschel et al. 2012; Vallon et al. 2015). The porin, PP 2662, and quinoprotein alcohol dehydrogenases PdeE and PdeH (PP_2674, PP_2679) of P. putida KT2440 are strongly induced by ethylene glycol but not by its oxidized byproduct glyoxylic acid (Mückschel et al. 2012). The substratebinding protein, PP_2676, under control of the PedR1 regulator, is highly induced in response to chloramphenicol and naphthalene (Fernandez et al. 2012). We presume that PP 2662 and PP_2676 could be involved in the transport and degradation of polyhydric alcohols, e.g., glucosylglycerol, which are accumulated during desiccation stress as compatible solutes. The nutrient starvation experienced by $P$. putida cells during the 18 days of desiccation probably increased the (p)ppGpp pool, a positive regulator of TonBdependent transporters, increasing the uptake of siderophore, vitamin B12, nickel complexes, or carbohydrates (Schauer et al. 2008; Zhang et al. 2019). Since water removal triggers iron oxidation of proteins (Labrude et al. 1987; Kamnev et al. 2020), desiccated cells, in turn, activated the TonB-dependent receptor (PP_1446) probably to scavenge iron. During dormant states, other bacteria also maintain active transcription of genes encoding antioxidant defenses and ion transport. For example, VBNC Vibrio cholerae cells upregulate genes responsible for the transport of iron (iron (III) ABC transporter) and preservation of DNA metabolism (Asakura et al. 2007). Novosphingobium sp. LH128 dormant cells overexpress genes encoding for catalases and 1-Cys peroxiredoxin and genes involved in the transport of ions across the membrane, such as homologs of cation/multidrug efflux pump proteins, $\mathrm{Na}+/ \mathrm{H}+327$ antiporter, copper resistance protein, and bacterioferritin (Fida et al. 2017). In line with this need of activating an antioxidant response, supplementation of culture medium with the antioxidant oxyrase or ROS scavengers resuscitates enterohemorrhagic Escherichia coli and Legionella pneumophila from the VBNC state (Reissbrodt et al. 2002; Ducret et al. 2014) suggesting that bacterial cells could be encountering oxidative stress during the formation of the VBNC state. Thus, relieving the oxidative stress with catalase or non-enzyme peroxide-degrading compounds restores cell culturability (Mizunoe et al. 1999; Liu et al. 2018). The TonB-dependent siderophore receptor is involved in the uptake of essential nutrients, including iron, which is essential for biofilm 
formation (Gulez et al. 2014; Luscher et al. 2018). Iron might be involved in the resuscitation of non-culturable bacteria since medium supplementation with ferrioxamine E resuscitates the VBNC Salmonella enterica cells (Reissbrodt et al. 2002). The mechanism of this effect is not clear. The authors proposed that ferrioxamine $\mathrm{E}$ can modulate the release and use of ferric iron preventing the generation oxygen free radicals (Reissbrodt et al. 2000; Reissbrodt et al. 2002). We would propose for desiccated P. putida cells (VBNC cells) that the accumulation of elevated ROS concentrations oxidize the $\mathrm{Fe}(\mathrm{II})$ catalytic cofactor of a wide variety of non-redox enzymes and the [4Fe-4S] clusters of dehydratases triggering the mismetallation of these enzymes thereby disrupting metabolism (Gu and Imlay 2013). The bacteria in response activate iron-import, normally with ferric iron-chelating substances under aerobic conditions but delivering ferrous iron into the cytoplasm, to restore the activity of mismetallated enzymes thus preserving the fundamental cellular functions of cells (Beauchene et al. 2017). Bacteria do not activate ferrous iron transport systems under aerobic conditions but reduce a significant proportion of ferric-iron assimilated from the media to ferrous-iron during aerobic iron assimilation (Kamnev et al. 2014; Beauchene et al. 2017). Therefore, the activation of the ferriciron transport system observed in this work by the overexpression of the TonB-dependent receptor could be a potential strategy used by $P$. putida KT2440 to provide the ferrous-iron required for vital functions during the VBNC state. In fact, activation of ferric iron-import genes is one of the strategies used by $E$. coli for the re-metallation of superoxide damaged mononuclear iron enzymes. The resultant apoproteins can either quickly re-bind iron or inappropriately bind zinc (Gu and Imlay 2013). Curiously, a mutant lacking the TonB-dependent receptor gene (PP_1446) was more resistant to desiccation so that cells remained viable longer (Fig. 4). Since intracellular iron catalyzes the Fenton chemistry, the scarce amount of intracellular iron accumulated into the TonB-dependent receptor mutant cells could be limiting the ROS and Fenton chemistry damage during desiccation stress, enabling the PP_1446 mutant strain to survive longer than the parental strain (Frawley and Fang 2014). Although this explanation could appear paradoxical, it is not. We speculate that the iron import during the desiccated state does not provide the substrate for Fenton reactions but cofactors for un-metallated apoproteins through an unknown mechanism that directly delivers the $\mathrm{Fe}^{2+}$ into the active sites of damaged iron enzymes. Further experiments should be performed to explain the observed behavior of the PP_1446 mutant strain. Finally, we cannot discharge transcriptional changes associated with the change from LB to water. Even stationary phase cells of $P$. putida were washed, resuspended in distilled water, and maintained in this milieu for $1 \mathrm{~h}$ before RNA extraction of "day 0" samples. We cannot discharge the putative transcriptional changes associated with nutritional stress, low-salt stress, and iron starvation induced by transfer cells from LB medium to distilled water. So, the findings of this study can carry out a potential response associated with the mentioned stresses. Further experiments with stationary phase cells resuspended in distilled water and maintained in this setting (without desiccation) for 18 days as non-desiccated control cells will be required to discard the transcriptional changes associated with the change from LB to water.

\section{Conclusions}

Desiccation causes loss of culturability of $P$. putida KT2440 making cells enter the VBNC state as a longterm survival strategy. During this dormant state, $P$. putida maintains active transmembrane transport processes like siderophore and putative polyhydric alcohol transport systems. Prolonged rehydration with distilled water resuscitates $P$. putida KT2440 cells activating the catabolism of phenylalanine/tyrosine to provide energy and carbon for ubiquinone biosynthesis while maintaining reduced protein synthesis.

\section{Materials and methods}

Bacterial strains and growth conditions

Pseudomonas putida KT2440, a plasmid-free derivative of $P$. putida mt-2 was used in the present study (Nelson et al. 2002). Mutant strains were donated by the Consejo Superior de Investigaciones Científicas, Estación Experimental del Zaidín (CSIC-EEZ). The collection of mutants of P. putida KT2440 was obtained by random mutagenesis using the miniTn5 $(\mathrm{Km})$ transposon. The transposon insertion was identified by arbitrary PCR (Molina-Henares et al. 2010). The strains used in this work are shown in Table 2. P. putida KT2440 was grown at $30{ }^{\circ} \mathrm{C}$ in LB (Luria-Bertani) liquid medium supplemented with $100 \mu \mathrm{g} / \mathrm{mL}$ chloramphenicol and constant agitation. Mutant strains were grown in LB medium supplemented with $100 \mu \mathrm{g} / \mathrm{mL}$ chloramphenicol and $50 \mu \mathrm{g} / \mathrm{mL}$ kanamycin.

\section{Bacterial desiccation assays}

P. putida KT2440 strain and mutant strains were grown until the stationary phase in LB liquid medium supplemented with antibiotics because at this growth phase cells exhibit higher survival to desiccation than cells in the exponential phase (Muñoz-Rojas et al. 2006). Thus, cultures were incubated for $24 \mathrm{~h}$ to ensure cells had reached the stationary phase as shown in the growth curve in the supplementary Figure S2. The growth curve of wild type and mutant strains was similar, all of them reached $\log (\mathrm{CFU} / \mathrm{mL})=9.77 \pm 0.37$ in $24 \mathrm{~h}$. Three independent experiments of desiccation assays were performed as described in an established protocol (Molina- 
Romero et al. 2017). The cells were centrifuged, washed twice with sterile distilled water, and resuspended in distilled water with the initial volume. Subsequently, the cell suspension was aliquoted in $1.5 \mathrm{~mL}$ tubes with $500 \mu \mathrm{L}$ each tube and covered with a sterile cotton cap. The tubes with cell suspension were placed in a desiccation chamber for 18 days at $30{ }^{\circ} \mathrm{C}$ and $50 \%$ relative humidity. Every 3 days after the beginning of desiccation, bacterial survival was determined using five sample tubes. Desiccated samples were rehydrated for $20 \mathrm{~min}$ with sterile distilled water to the initial volume. After letting the biomass-powder suspensions sit at room temperature for $20 \mathrm{~min}$, samples were mixed by pipetting up and down for $10 \mathrm{~s}$, then serially diluted and streaked onto LB-agar plates. Twenty minutes of rehydration was the minimal time necessary to disaggregate the agglomeration of dried cells. After 18 days of desiccation, samples were rehydrated for $20 \mathrm{~min}$ or $24 \mathrm{~h}$. Twenty-four hours of rehydration was the minimal time required for dormant $P$. putida cells to return to the cultivable state according to the time profile of bacterial resuscitation (Pazos-Rojas et al. 2019). The number of $\mathrm{CFU} / \mathrm{ml}$ was monitored by the drop plate method. Three replicates per sample were used.

\section{RNA extraction, reverse transcription (RT), and labeling for microarrays}

RNA extraction: Total RNA was extracted from $P$. putida KT2440 at day 0 (these are non-desiccated control cells that were grown until stationary phase, washed, aliquoted into $1.5 \mathrm{~mL}$ tubes, and maintained at this milieu $1 \mathrm{~h}$ ) and from cells after 18 days of desiccation and which had been rehydrated for $20 \mathrm{~min}$ or $24 \mathrm{~h}$ before RNA extraction. A pool of 30 sample tubes was used for RNA extraction of each condition. The cell suspensions were extracted using TRI Reagent (Ambion) and BCP (1-Bromo-3-chloropropane); RNA was precipitated with isopropanol and washed with $70 \%$ ethanol. Finally, RNA was resuspended in DEPC water. To eliminate DNA contamination, the samples were treated with TURBO DNA-free kit (Invitrogen). RNA concentration and purity were determined using a NanoDrop 2000/ 2000c spectrophotometer (Thermo Scientific).

cDNA Synthesis and labeling cDNA probes were generated by reverse transcription using SuperScript II (Invitrogen). The reaction mixture contained $20 \mu \mathrm{g}$ of total RNA and $7.5 \mu \mathrm{g}$ of $\operatorname{pd}(\mathrm{N}) 6$ random hexamer primer
(Amersham). Alkaline hydrolysis was used to eliminate non-transcript RNA in cDNA. Primers and dNTPs not incorporated were eliminated using the PCR purification kit (Qiagen). Then, cDNA was labeled: Cy3 fluorophore (CyTM3 monofunctional reactive dye; Amersham Pharmacia) was used to label samples before desiccation and CyTM5 fluorophore (CyTM5 monofunctional reactive dye; Amersham Pharmacia) was used to label samples after desiccation.

\section{Hybridization conditions and microarrays data analysis} Hybridization: Microarray slides (Progenika, Biopharma) were cleaned and immersed in a stop solution $(5 \times$ SSC; $0.1 \%$ SDS; $1 \%$ BSA) and washed twice with milli-Q water (Rodríguez-Herva et al. 2010). Labeled cDNA was rehydrated with $35 \mu \mathrm{L}$ of hybridization solution (5× SSC; $25 \%$ (v/v) formamide; $0.5 \%(\mathrm{p} / \mathrm{v})$ SDS; $5 \%(\mathrm{p} / \mathrm{v})$ dextran sulfate; $5 \times$ solution Denhardt's: Ficoll; polyvinylpyrrolidone; BSA). The mixture was placed on microarray slides and put in a hybridization chamber (ArrayIt Hybridization Cassette) for $20 \mathrm{~h}$ at $45^{\circ} \mathrm{C}$ immersed in a water bath. For each condition evaluated, three slides were used to eliminate irregular data. Microarray data acquisition and analysis: The slide was scanned in a 4100A Biochip Scanner (Axon Corporation, CA) and image data was analyzed in GenePix Pro 5.1 software. Differential gene expression and statistical analysis were performed with AlmaZen Software (Bioalma). Gene expression data were normalized with the following parameters: foldchange $<-2$ AND exp_level $>64$ AND $p$ value $>0.05$ OR foldchange $>2$ AND exp_level $>64$ AND $p$ value $<0.05$. Genes that showed differential expression were classified by Gene Ontology (The Pseudomonas Genome Database, http://www.pseudomonas.com) using biological process terms. Enrichment analysis was performed using the free online platform DAVID (Huang et al. 2018).

\section{Real-time quantitative reverse transcription-PCR (qRT- PCR)}

To validate microarray results upon 20 min rehydration, quantitative reverse transcription-PCR (qRT-PCR) was performed using the primers listed in Table 3. RNA extraction was performed using the hot acidic phenolchloroform method and genomic DNA was removed using the Invitrogen TURBO DNA-free Kit (Thermo Fisher Scientific) (Baez et al. 2009). Total RNA was

Table 2 Bacterial strains used in this study

\begin{tabular}{lll}
\hline Strains & Description & Reference \\
\hline P. putida KT2440 & Wild type & (Muñoz-Rojas et al. 2006) \\
P. putida 662 & Mutant derivative of KT2440 PP0256:kmR & (Molina-Henares et al. 2010) \\
P. putida 1157 & Mutant derivative of KT2440 PP3451::kmR & (Molina-Henares et al. 2010) \\
P. putida 1743 & Mutant derivative of KT2440 PP0880::kmR & (Molina-Henares et al. 2010) \\
P. putida 2409 & Mutant derivative of KT2440 PP1446::kmR & (Molina-Henares et al. 2010) \\
\hline
\end{tabular}


Table 3 qRT-PCR primers used in this study

\begin{tabular}{lll}
\hline Primer name & Sequence $\left(5^{\prime}---3^{\prime}\right)$ & Gene description \\
\hline $3451 \mathrm{~F}$ & TGGACAAGCCGTTGCATATC CTGCCACCACACAGTCAAG & Hypothetical protein \\
$3451 \mathrm{R}$ & CACCTGGCAGTTCATCCT TCAGTGACATCACCACTGAC & dppC-dipeptide ABC transporter permease \\
$880 \mathrm{~F}$ & & \\
$1446 \mathrm{~F}$ & TCAGCTCGGTCAAGGTAGAT & TonB-dependent receptor \\
$1446 \mathrm{R}$ & GCTTCGTAGCCCTTGTTCTT & \\
$256 \mathrm{~F}$ & CTGACCAGGCCGATTCTATAC & Molybdopterin oxidoreductase subunit \\
$256 \mathrm{R}$ & GAGCAGTCAGGGAGTTGTT & Substrate binding protein \\
$2676 \mathrm{~F}$ & GTACGCCTGCAACTGATCT & \\
$2676 \mathrm{R}$ & TCGGCCAATGCTGATGA & Ethylene glycol porin \\
$2662 \mathrm{~F}$ & CCAACTACCTAGGCTTCAACAT & \\
$2662 \mathrm{R}$ & GTTGGTTCACTGTCGTTGATG & \\
\hline
\end{tabular}

extracted from $P$. putida KT2440 at day 0 (these are nondesiccated control cells that were grown until stationary phase, washed, aliquoted into $1.5 \mathrm{ml}$ tubes, and maintained at this setting for $1 \mathrm{~h}$ ), and from cells subjected to 18 days of desiccation. Thus, RNA was isolated from desiccated cells without rehydration (WoR), desiccated cells with 20-min rehydration, and desiccated cells with $24 \mathrm{~h}$ rehydration. A pool of 15 sample tubes was used for RNA extraction of each condition. cDNA was generated by using $2 \mu \mathrm{g}$ RNA in a total volume of $20 \mu \mathrm{L}$ with $10 \mu \mathrm{M}$ of specific DNA primers (antisense primers Table 3) according to the protocol of the High Capacity cDNA Reverse Transcription Kit (Applied Biosystems). Real-time qRT-PCR was performed using an Applied Biosystems 7500 Fast Real-Time PCR System. SYBR Green PCR Master Mix was used as a signal reporter. Each reaction was composed of $20 \mathrm{ng}$ of cDNA and $6 \mu \mathrm{M}$ of each pair of primers in a total volume of $20 \mu \mathrm{L}$. The following amplification conditions were used: 1 cycle of $5 \mathrm{~min}$ at $95{ }^{\circ} \mathrm{C}$ followed by 30 cycles of denaturation at $95{ }^{\circ} \mathrm{C}$ for $30 \mathrm{~s}$ and annealing and extension at $55{ }^{\circ} \mathrm{C}$ for $30 \mathrm{~s}$. Each reaction was performed in triplicate. The expression of the $r p o N$ gene (encoding the sigma factor 54) was used as an endogenous control to normalize the amount of mRNA obtained from a target gene (Yuste et al. 2006; Follonier et al. 2013). Data were analyzed using the $2^{-\Delta \Delta C}$ method (Livak and Schmittgen 2001).

\section{Statistical analysis}

The statistical analysis of qRT-PCR results was performed using Sigma Plot (Handel Scientific Software). Data were analyzed globally by ANOVA single factor, and significant treatment effects were determined by the Tukey-Kramer post hoc test.

\section{Supplementary information}

Supplementary information accompanies this paper at https://doi.org/10. 1186/s13213-020-01596-3.

Additional file 1: Table S1. List of differentially expressed genes after $24 \mathrm{~h}$ of rehydration and their fold changes.
Additional file 2: Figure S1. qRT-PCR analysis of genes PP_2676 and PP_2662 in desiccated P. putida KT2440 followed by rehydration. "BD" means before desiccation and refers to non-desiccated control cells. WoR indicates that RNA was extracted from desiccated bacteria prior to rehydration. $20 \mathrm{~min}$ and $24 \mathrm{~h}$ indicate that 18 days-desiccated bacteria were rehydrated for $20 \mathrm{~min}$ or $24 \mathrm{~h}$ before RNA extraction. Error bars represent the standard deviation of three replicates.

Additional file 3: Figure S2. Growth curve of $P$. putida KT2440 in LB medium at $30{ }^{\circ} \mathrm{C}$ in $250 \mathrm{~mL}$ shake flask. Bacterial counts and optical density time profile. Error bars represent the standard deviation of triplicate cultures.

Additional file 4: Figure S3. Phenylalanine and tyrosine biosynthesis pathway highlighting the upregulated genes in desiccated-24 $\mathrm{h}$ rehydrated P. putida cells.

Additional file 5: Figure S4. Phenylalanine catabolism and ubiquinone biosynthesis pathway. In red are highlighted the gene products that were up- and downregulated in desiccated- $24 \mathrm{~h}$ rehydrated $P$. putida cells.

\section{Abbreviations}

CFU: Colony-forming unit; DEPC: Diethyl pyrocarbonate; GFP: Green fluorescent protein; GO: Gene ontology; PGPR: Plant growth-promoting rhizobacteria; qRT-PCR: Quantitative reverse transcription-PCR; ROS: Reactive oxygen species; VBNC: Viable but nonculturable; WoR: Without rehydration

\section{Acknowledgements}

We are grateful to the Pseudomonas Reference Culture Collection of the EEZ-CSIC (http://artemisa.eez.csic.es/prcc/) for providing the mutant strains.

\section{Authors' contributions}

$A B, L I L L$, and JMR conceived, designed and directed the project, interpreted the data and designed the figures. LILL and LAPR conducted the experiments. LELC performed qRT-PCR of desiccated cells. YEMG and VQH supervised the work and administrated the project. LAPR, JDLT, and PVD manufactured the samples and performed the microarray experiments. $A B$ took the lead in writing the manuscript. The author(s) read and approved the final manuscript.

\section{Funding}

Funding was provided by the intramural program of the Vicerrectoria de Investigación y Estudios de Posgrado, BUAP through grants PV16-ID00450, PV17-ID00337. Lilia Isela Lopez Lara received a scholarship (number 273274) from the National Council of Science and Technology (CONACyT). Competing interests

The authors declare that they have no conflicts of interest.

\section{Availability of data and materials}

The complete list of differentially expressed genes at $24 \mathrm{~h}$ rehydration and their fold change are presented in Table S1. 


\section{Ethics approval and consent to participate}

Not applicable.

\section{Consent for publication}

Not applicable.

\section{Author details}

${ }^{1}$ Centro de Investigaciones en Ciencias Microbiológicas, Instituto de Ciencias, Benemérita Universidad Autónoma de Puebla, Puebla, México. ${ }^{2}$ Facultad de Ciencias Biológicas, Benemérita Universidad Autónoma de Puebla, Puebla, México. ${ }^{3}$ CONACYT, Centro de Investigaciones en Ciencias Microbiológicas, Instituto de Ciencias, Benemérita Universidad Autónoma de Puebla, Puebla, México. ${ }^{4}$ Department of Environmental Protection, Estación Experimental del Zaidín, Consejo Superior de Investigaciones Científicas, Granada, Spain. ${ }^{5}$ Laboratorio de Ecología Molecular Microbiana, Centro de Investigaciones en Ciencias Microbiológicas, Instituto de Ciencias, Benemérita Universidad Autónoma de Puebla, Av. San Claudio S/N, CP. 72570 Puebla, México.

\section{Received: 5 February 2020 Accepted: 28 August 2020}

Published online: 14 September 2020

\section{References}

Asakura H, Ishiwa A, Arakawa E, Makino S, Okada Y, Yamamoto S, Igimi S (2007) Gene expression profile of Vibrio cholerae in the cold stress-induced viable but non-culturable state. Environ Microbiol 9:869-879. https://doi.org/10. 1111/j.1462-2920.2006.01206.x

Baez A, Flores N, Bolívar F, Ramírez OT (2009) Metabolic and transcriptional response of recombinant Escherichia coli to elevated dissolved carbon dioxide concentrations. Biotechnol Bioeng 104:102-110. https://doi.org/10. 1002/bit.22379

Beauchene NA, Mettert EL, Moore LJ, Keleş S, Willey ER, Kiley PJ (2017) O2 availability impacts iron homeostasis in Escherichia coli. Proc Natl Acad Sci U S A 114:12261-12266. https://doi.org/10.1073/pnas.1707189114

Bédard E, Charron D, Lalancette C, Déziel E, Prévost M (2014) Recovery of Pseudomonas aeruginosa culturability following copper- and chlorineinduced stress. FEMS Microbiol Lett 356:226-234. https://doi.org/10.1111/ 1574-6968.12494

Belda E, van Heck RGA, Lopez-Sanchez JM, Cruveiller S, Barbe V, Fraser C, Klenk HP, Petersen J, Morgat A, Nikel PI, Vallenet D, Rouy Z, Sekowska A, Martins Dos Santos VA, de Lorenzo V, Danchin A, Médigue C (2016) The revisited genome of Pseudomonas putida KT2440 enlightens its value as a robust metabolic chassis. Environ Microbiol 18:3403-3424. https://doi.org/10.1111/ 1462-2920.13230

Chang WS, van De Mortel M, Nielsen L, De Guzman GN, Li X, Halverson L (2007) Alginate production by Pseudomonas putida creates a hydrated microenvironment and contributes to biofilm architecture and stress tolerance under water-limiting conditions. J Bacteriol 189:8290-8299. https:// doi.org/10.1128/JB.00727-07

Chen S, Li X, Wang Y, Zeng J, Ye C, Li X, Yu X (2018) Induction of Escherichia coli into a VBNC state through chlorination/chloramination and differences in characteristics of the bacterium between states. Water Res 142:279-288. https://doi.org/10.1016/j.watres.2018.05.055

Ducret A, Chabalier M, Dukan S (2014) Characterization and resuscitation of "nonculturable" cells of Legionella pneumophila. BMC Microbiol 14:3. https://doi. org/10.1186/1471-2180-14-3

Enebe MC, Babalola OO (2018) The influence of plant growth-promoting rhizobacteria in plant tolerance to abiotic stress: a survival strategy. Appl Microbiol Biotechnol 102:7821-7835. https://doi.org/10.1007/s00253-0189214-z

Espinosa-Urgel M, Kolter R, Ramos JL (2002) Root colonization by Pseudomonas putida: love at first sight. Microbiol 148:341-344

Fernandez M, Niqui-Arroyo JL, Conde S, Ramos JL, Duque E (2012) Enhanced tolerance to naphthalene and enhanced rhizoremediation performance for Pseudomonas putida KT2440 via the NAH7 catabolic plasmid. Appl Environ Microbiol 78:5104-5110. https://doi.org/10.1128/AEM.00619-12

Fida TT, Moreno-Forero SK, Breugelmans P, Heipieper HJ, Röling WFM, Springae D (2017) Physiological and transcriptome response of the polycyclic aromatic hydrocarbon degrading Novosphingobium sp. LH128 after inoculation in Soil. Environ Sci Technol 51:1570-1579 doi.org/10.1021/acs.est.6b03822

Follonier S, Escapa IF, Fonseca PM, Henes B, Panke S, Zinn M, Prieto MA (2013) New insights on the reorganization of gene transcription in Pseudomonas putida KT2440 at elevated pressure. Microb Cell Factories 12:30. https://doi. org/10.1186/1475-2859-12-30

Frawley ER, Fang FC (2014) The ins and outs of bacterial iron metabolism. Mol Microbiol 93:609-616. https://doi.org/10.1111/mmi.12709

Gennaris A, Ezraty B, Henry C, Agrebi R, Vergnes A, Oheix E, Bos J, Leverrier P, Espinosa L, Szewczyk J, Vertommen D, Iranzo O, Collet JF, Barras F (2015) Repairing oxidized proteins in the bacterial envelope using respiratory chain electrons. Nature 528:409-412. https://doi.org/10.1038/nature15764

Green J, Stapleton MR, Smith LJ, Artymiuk PJ, Kahramanoglou C, Hunt DM, Buxton RS (2014) Cyclic-AMP and bacterial cyclic-AMP receptor proteins revisited: adaptation for different ecological niches. Curr Opin Microbiol 18:17. https://doi.org/10.1016/j.mib.2014.01.003

Gu M, Imlay JA (2013) Superoxide poisons mononuclear iron enzymes by causing mismetallation. Mol Microbiol 89:123-134. https://doi.org/10.1111/mmi.12263

Gülez G, Dechesne A, Workman CT. Smets BF (2012) Transcriptome dynamics of Pseudomonas putida KT2440 under water stress. Appl Environ Microbiol 78: 676-683. https://doi.org/10.1128/AEM.06150-11

Gulez G, Altintaş A, Fazli M, Dechesne A, Workman CT, Tolker-Nielsen T, Smets BF (2014) Colony morphology and transcriptome profiling of Pseudomonas putida KT2440 and its mutants deficient in alginate or all EPS synthesis under controlled matric potentials. MicrobiologyOpen 3:457-469. https://doi.org/10. $1002 / \mathrm{mbo3} .180$

Hayat R, Ali S, Amara U, Khalid R, Ahmed I (2010) Soil beneficial bacteria and their role in plant growth promotion: a review. Ann Microbiol 60:579-598. https:// doi.org/10.1007/s13213-010-0117-1

Herrera MC, Daddaoua A, Fernández-Escamilla A, Ramos JL (2012) Involvement of the global Crp regulator in cyclic AMP-dependent utilization of aromatic amino acids by Pseudomonas putida. J Bacteriol 194:406-412. https://doi.org/ 10.1128/JB.06353-11

Huang DW, Sherman BT, Lempicki RA (2018) Systematic and integrative analysis of large gene lists using DAVID bioinformatics resources. Nat Protoc. 4:44-57. https://doi.org/10.1038/nprot.2008.211.

Kamnev AA, Tugarova AV, Kovács K, Biró B, Homonnay H, Kuzmann E (2014) Mössbauer spectroscopic study of 57Fe metabolic transformations in the rhizobacterium Azospirillum brasilense Sp245. Hyperfine Interact 226:415-419. doi.org/10.1007/s10751-013-0929-z.

Kamnev AA, Tugarova AV, Shchelochkov AG, Kovács K, Kuzmann E (2020) Diffuse reflectance infrared Fourier transform (DRIFT) and Mössbauer spectroscopic study of Azospirillum brasilense Sp7: Evidence for intracellular iron(II) oxidation in bacterial biomass upon lyophilisation. Spectrochimica Acta Part A: Molecular and Biomolecular Spectroscopy 229: 2020,117970. doi.org/10.1 016/j.saa.2019.117970.

Kan Y, Jiang N, Xu X, Lyu Q, Gopalakrishnan V, Walcott R, Burdman S, Li J, Luo L (2019) Induction and resuscitation of the viable but non-culturable (VBNC) state in Acidovorax citrulli, the causal agent of bacterial fruit blotch of cucurbitaceous crops. Front Microbiol 10:1081. https://doi.org/10.3389/fmicb.2019.01081

Kets EP, Galinski EA, de Wit M, de Bont JA, Heipieper HJ (1996) Mannitol, a novel bacterial compatible solute in Pseudomonas putida S12. J Bacteriol 178:66656670. https://doi.org/10.1128/jb.178.23.6665-6670.1996

Kloepper JW, Lifshitz R, Zablotowicz RM (1989) Free-living bacterial inocula for enhancing crop productivity. Trends Biotechnol 7:39-44. https://doi.org/10. 1016/0167-7799(89)90057-7

Kurz M, Burch AY, Seip B, Lindow SE, Gross H (2010) Genome-driven investigation of compatible solute biosynthesis pathways of Pseudomonas syringae pv. syringae and their contribution to water stress tolerance. Appl Environ Microbiol 76:5452-5462. https://doi.org/10.1128/AEM.00686-10

Labrude P, Chaillot B, Vigneron C (1987) Problems of haemoglobin freeze-drying: evidence that water removal is the key to iron oxidation. J Pharm Pharmacol 39:344-348. https://doi.org/10.1111/j.2042-7158.1987.tb03396.x

Lebre PH, De Maayer P, Cowan DA (2017) Xerotolerant bacteria: surviving through a dry spell. Nat Rev Microbiol 15:285-296. https://doi.org/10.1038/nrmicro.2017.16

Liu H, Xiao Y, Nie H, Huang Q, Chen W (2017) Influence of (p)ppGpp on biofilm regulation in Pseudomonas putida KT2440. Microbiol Res 204:1-8. https://doi. org/10.1016/j.micres.2017.07.003

Liu J, Deng Y, Li L, Li B, Li Y, Zhou S, Peters BM (2018) Discovery and control of culturable and viable but non-culturable cells of a distinctive Lactobacillus harbinensis strain from spoiled beer. Sci Rep 8:2-11. https://doi.org/10.1038/ s41598-018-28949-y

Livak KJ, Schmittgen TD (2001) Analysis of relative gene expression data using real-time quantitative $P C R$ and the 2- $\Delta \Delta C T$ method. Methods 25:402-408. https://doi.org/10.1006/meth.2001.1262 
Luscher A, Moynié L, Auguste PS, Bumann D, Mazza L, Pletzer D, Naismith JH, Köhler T (2018) TonB-dependent receptor repertoire of Pseudomonas aeruginosa for uptake of siderophore-drug conjugates. Antimicrob Agents Chemother 62:e00097-e00018. https://doi.org/10.1128/AAC.00097-18

Manzanera M, García de Castro A, Tøndervik A, Rayner-Brandes M, Strøm AR, Tunnacliffe A (2002) Hydroxyectoine is superior to trehalose for anhydrobiotic engineering of Pseudomonas putida KT2440. Appl Environ Microbiol 68:4328-4333. https://doi.org/10.1128/AEM.68.9.4328-4333.2002

Mizunoe Y, Wai SN, Takade A, Yoshida SI (1999) Restoration of culturability of starvation-stressed and low- temperature-stressed Escherichia coli 0157 cells by using H2O2-degrading compounds. Arch Microbiol 172:63-67. https://doi. org/10.1007/s002030050741

Molina L, Ramos C, Duque E, Ronchel MC, Garcia JM, Wyke L, Ramos JL (2000) Survival of Pseudomonas putida KT2440 in soil and in the rhizosphere of plants under greenhouse and environmental conditions. Soil Biol Biochem 32:315-321. https://doi.org/10.1016/S0038-0717(99)00156-X

Molina-Henares MA, de la Torre J, García-Salamanca A, Molina-Henares AJ, Herrera MC, Ramos JL, Duque E (2010) Identification of conditionally essential genes for growth of Pseudomonas putida KT2440 on minimal medium through the screening of a genome-wide mutant library. Environ Microbiol 12:1468-1485. https://doi.org/10.1111/j.1462-2920.2010.02166.x

Molina-Romero D, Baez A, Quintero-Hernández V, Castañeda-Lucio M, FuentesRamírez LE, Bustillos-Cristales M DR, Muñoz-Rojas J (2017) Compatible bacterial mixture, tolerant to desiccation, improves maize plant growth. PLoS One 12: e0187913. doi.org/10.1371/journal.pone.0187913.

Mückschel B, Simon O, Klebensberger J, Graf N, Rosche B, Altenbuchner J, Pfannstiel J, Huber A, Hauer B (2012) Ethylene glycol metabolism by Pseudomonas putida. Appl Environ Microbiol 78:8531-8539. https://doi.org/ 10.1128/AEM.02062-12

Muñoz-Rojas J, Bernal P, Duque E, Godoy P, Segura ARJ (2006) Involvement of cyclopropane fatty acids in the response of Pseudomonas putida KT2440 to freeze-drying. Appl Environ Microbiol 72:472-477. https://doi.org/10.1128/ AEM.72.1.472-477.2006

Nelson KE, Weinel C, Paulsen IT, Dodson RJ, Hilbert H, Martins dos Santos VAP, Fouts DE, Gill SR, Pop M, Holmes M, Brinkac L, Beanan M, DeBoy RT, Daugherty S, Kolonay J, Madupu R, Nelson W, White O, Peterson J, Khouri H, Hance I, Chris Lee P, Holtzapple E, Scanlan D, Tran K, Moazzez A, Utterback T, Rizzo M, Lee K, Kosack D, Moestl D, Wedler H, Lauber J, Stjepandic D, Hoheisel J, Straetz M, Heim S, Kiewitz C, Eisen JA, Timmis KN, Düsterhöft A, Tümmler B, Fraser CM (2002) Complete genome sequence and comparative analysis of the metabolically versatile Pseudomonas putida KT2440. Environ Microbiol 4:799-808. https://doi.org/10.1046/j.1462-2920.2002.00366.x

Paul D, Nair S (2008) Stress adaptations in a plant growth promoting rhizobacterium (PGPR) with increasing salinity in the coastal agricultural soils. J Basic Microbiol 48:378-384. https://doi.org/10.1002/jobm.200700365

Pazos-Rojas LA, Muñoz-Arenas LC, Rodríguez-Andrade O, López-Cruz LE, LópezOrtega O, Lopes-Olivares F, Luna-Suarez S, Baez A, Morales-García YE, Quintero-Hernández V, Villalobos-López MA, de la Torre J, Muñoz-Rojas J (2019) Desiccation-induced viable but nonculturable state in Pseudomonas putida KT2440, a survival strategy. PLoS One 14:e0219554. https://doi.org/10. 1371/journal.pone.0219554

Pocard JA, Smith LT, Smith GM, Le Rudulier D (1994) A prominent role for glucosylglycerol in the adaptation of Pseudomonas Mendocina SKB70 to osmotic stress. J Bacteriol 176:6877-6884. https://doi.org/10.1128/jb.176.22. 6877-6884.1994

Potts M (1994) Desiccation tolerance of prokaryotes. Microbiol Rev 58:755-805

Potts M, Slaughter SM, Hunneke FU, Garst JF, Helm RF (2005) Desiccation tolerance of prokaryotes: Application of principles to human cells. Integr Comp Biol 45:800-809. https://doi.org/10.1093/icb/45.5.800

Purvis JE, Yomano LP, Ingram LO (2005) Enhanced trehalose production improves growth of Escherichia coli under osmotic stress. Appl Environ Microbiol 71:3761-3769. https://doi.org/10.1128/AEM.71.7.3761-3769.2005

Reissbrodt R, Heier H, Tschape H, Kingsley RA, Williams PH (2000) Resuscitation by ferrioxamine $\mathrm{E}$ of stressed Salmonella enterica serovar typhimurium from soil and water microcosms. Appl Environ Microbiol 66:4128-4130. https://doi. org/10.1128/AEM.66.9.4128-4130.2000

Reissbrodt R, Rienaecker I, Romanova JM, Freestone PPE, Haigh RD, Lyte M, Tschäpe H, Williams PH (2002) Resuscitation of Salmonella enterica serovar typhimurium and enterohemorrhagic Escherichia coli from the viable but nonculturable state by heat-stable enterobacterial autoinducer. Appl Environ Microbiol 68:4788-4794. https://doi.org/10.1128/AEM.68.10.4788
Roberson EB, Firestone MK (1992) Relationship between desiccation and exopolysaccharide production in a soil Pseudomonas sp. Appl Environ Microbiol 58:1284-1291

Rodríguez-Herva JJ, Duque E, Molina-Henares MA, Navarro-Avilés G, Van Dillewijn P, de la Torre J, Molina-Henares AJ, La Campa AS, Ran FA, Segura A, Shingler V, Ramos JL (2010) Physiological and transcriptomic characterization of a fliA mutant of Pseudomonas putida KT2440. Environ Microbiol Rep 2:373-380. https://doi.org/10.1111/j.1758-2229.2009.00084.x

Schauer K, Rodionov DA, de Reuse H (2008) New substrates for TonB-dependent transport: do we only see the 'tip of the iceberg'? Trends Biochem Sci 33: 330-338. https://doi.org/10.1016/j.tibs.2008.04.012

Song S, Wood TK (2020) ppGpp ribosome dimerization model for bacterial persister formation and resuscitation. Biochem Biophys Res Commun 253: 281-286. doi.org/10.1016/j.bbrc.2020.01.102.

Vallon T, Simon O, Rendgen-Heugle B, Frana S, Mückschel B, Broicher A, Siemann-Herzberg M, Pfannenstiel J, Hauer B, Huber A, Breuer M, Takors R (2015) Applying systems biology tools to study n-butanol degradation in Pseudomonas putida KT2440. Eng Life Sci 15:760-771

Vogt SL, Green C, Stevens KM, Day B, Erickson DL, Woods DE, Storey DG (2011) The stringent response is essential for Pseudomonas aeruginosa virulence in the rat lung agar bead and Drosophila melanogaster feeding models of infection. Infect Immun 79:4094-4104. https://doi.org/10.1128/IAI.00193-11

Williams MJ, Shanley CA, Zilavy A, Peixoto B, Manca C, Kaplan G, Orme IM, Mizrahi $\vee$, Kana BD (2015) bis-Molybdopterin guanine dinucleotide is required for persistence of Mycobacterium tuberculosis in guinea pigs. Infect Immun 83:544-550. https://doi.org/10.1128/IAl.02722-14

Xia Z, Lei L, Zhang HY, Wei HL (2018) Characterization of the ModABC molybdate transport system of Pseudomonas putida in nicotine degradation. Front Microbiol 9:3030. https://doi.org/10.3389/fmicb.2018.03030

Yuste L, Hervás AB, Canosa I, Tobes R, Jiménez Jl, Nogales J, Pérez-Pérez MM, Santero E, Díaz E, Ramos JL, de Lorenzo V, Rojo F (2006) Growth phasedependent expression of the Pseudomonas putida KT2440 transcriptional machinery analysed with a genome-wide DNA microarray. Environ Microbiol 8:165-177. https://doi.org/10.1111/j.1462-2920.2005.00890.x

Zhang Q, Yan T (2012) Correlation of intracellular trehalose concentration with desiccation resistance of soil Escherichia coli populations. Appl Environ Microbiol 78:7407-7413. https://doi.org/10.1128/AEM.01904-12

Zhang S, Ye C, Lin H, Lv L, Yu X (2015) UV disinfection induces a vbnc state in Escherichia coli and Pseudomonas aeruginosa. Environ Sci Technol 49:17211728. https://doi.org/10.1021/es505211e

Zhang Y, Teper D, Xu J, Wang N (2019) Stringent response regulators (p)ppGpp and DksA positively regulate virulence and host adaptation of Xanthomonas citri. Mol Plant Pathol 20:1550-1565. https://doi.org/10.1111/mpp.12865

\section{Publisher's Note}

Springer Nature remains neutral with regard to jurisdictional claims in published maps and institutional affiliations.

Ready to submit your research? Choose BMC and benefit from:

- fast, convenient online submission

- thorough peer review by experienced researchers in your field

- rapid publication on acceptance

- support for research data, including large and complex data types

- gold Open Access which fosters wider collaboration and increased citations

- maximum visibility for your research: over $100 \mathrm{M}$ website views per year

At $\mathrm{BMC}$, research is always in progress.

Learn more biomedcentral.com/submissions 